\title{
Research Unchained:
}

The Multidisciplinary Future of Antislavery Studies

A Special Issue of the Journal of Modern Slavery in collaboration with the Antislavery Early Research Project supported by the AHRC Antislavery Usable Past

\section{Approaching Contemporary Slavery Through an Historic Lens: an Interdisciplinary Perspective}

\section{Rebecca Nelson}

Alicia Kidd

$\mathrm{PhD}$ candidates

Volume 4, Issue 2

December 2018 


\title{
Approaching Contemporary Slavery Through an Historic Lens: an Interdisciplinary Perspective
}

\section{Rebecca Nelson}

Rebecca is an AHRC-funded PhD candidate on the Antislavery Usable Past Project (http:// www.antislavery.ac.uk/), based at the University of Hull. Rebecca's research examines the way in which museums across the UK engage with antislavery, as both an historic and a contemporary issue. She has used a mixed-methods approach to her research, working closely with museum professionals, to identify the key challenges of interpreting antislavery for public audiences. Prior to this she completed a BA Hons Degree in History at the University of York and an MA in Museum Studies at Newcastle University.

\begin{abstract}
Alicia Kidd
Alicia is a third year $\mathrm{PhD}$ candidate, researching the relationship between conflict and contemporary slavery using empirical, qualitative research based on interviews with individuals who have fled conflict zones and individuals who have experienced contemporary slavery. She has worked in the field of contemporary slavery since 2012, and currently holds the post of Vice Chair of the Humber Modern Slavery Partnership. Alicia recently received a High Sheriff's award in recognition of great and valuable services to the community in relation to her work on contemporary slavery.
\end{abstract}

\section{Acknowledgements}

Thanks to the staff and researchers at the Wilberforce Institute who are always on hand with enlightening ideas. A particular thank you to Professor John Oldfield for his comments on this piece and for continuing to encourage our progression as academics.

\begin{abstract}
This article uses an interdisciplinary approach combining social justice and history to address and offer a response to critiques that argue 'slavery' is not an appropriate term for present day cases of extreme exploitation. By analysing the means and modalities through which situations of slavery are established and maintained across various temporal and geographical examples, this article highlights how the practices of the past persist in the present.
\end{abstract}

Key words: contemporary slavery, transatlantic slavery, legality, othering 


\section{Approaching Contemporary Slavery Through an Historic Lens: an Interdisciplinary Perspective}

\section{Introduction}

'Charges of slavery are unlikely to be politically compelling... when they rest on a limited historical foundation'. ${ }^{1}$

Current critiques regarding the use of the term slavery to refer to contemporary practices rest heavily on a construction of significant difference between historic slavery and that which occurs in the present. ${ }^{2}$ As Joel Quirk implies in the quotation above, use of the term 'slavery' in the present is flawed if it fails to consider the long history of slavery across the world. However, those critical of using the term 'slavery' to describe contemporary practices fail in the same way by focusing predominantly on comparing current situations with transatlantic slavery alone, thus overlooking other examples of historic slavery. Using a unique interdisciplinary approach, this article combines practitioner experience with ideas of both social justice and history. Whilst there are clearly distinct differences between historic and contemporary slavery, this article highlights some of the complex commonalities across examples drawn form a wide temporal and geographical range to demonstrate that the concept of slavery is one still relevant today. ${ }^{3}$

There continues to be no universally accepted definition of contemporary slavery. While there are numerous definitions that could be employed, the Bellagio-Harvard Guidelines are used here. They provide an approach that combines both the legal definitions and lived experience of slavery, and offer a definition that allows historic and contemporary slavery to be understood under the same rubric. The overarching theme of these guidelines is:

\footnotetext{
${ }^{1}$ Joel Quirk, The Anti-slavery Project: From the Slave Trade to Human Trafficking (Philadelphia: University of Pennsylvania Press, 2011), 250.

2 Julia O’Connell Davidson, "Rights Talk, Wrong Comparison: Trafficking and Transatlantic Slavery,” 1 June, 2015, Beyond Trafficking and Slavery, https://www.opendemocracy.net/beyondslavery/julia-0\%27connell-davidson/rightstalk-wrong-comparison-trafficking-and-transatlantic-sl.

${ }^{3}$ Although legal and theoretical writing more commonly references 'modern slavery', this piece uses 'contemporary slavery'. This is to avoid confusion around what constitutes 'modern' and what constitutes 'historic' slavery when the modern period of history dates back to around 1750. David Brion Davis explores the foundations of Transatlantic Slavery, which he calls 'Modern Slavery', in relation to the examples of enslavement in the ancient world that provide the grounding for his analysis. See: David Brion Davis, Inhuman Bondage: The Rise and Fall of Slavery in the New World (Oxford: Oxford University Press, 2006), 27.
} 
In cases of slavery, the exercise of 'the powers attaching to the right of ownership' should be understood as constituting control over a person in such a way as to significantly deprive that person of his or her individual liberty, with the intent of exploitation through the use, management, profit, transfer or disposal of that person. Usually this exercise will be supported by and obtained through means such as violent force, deception and/or coercion. ${ }^{4}$

The primary concern of this article is not definitions, but the means and modalities through which situations of slavery are established and maintained. Taking inspiration from the Bellagio-Harvard Guidelines and the common traits identified by historians of slavery, this piece addresses some of the key methods that enable(d) slavery to exist both in the past and in the present; these themes are used to structure the article. 5

Firstly, inherent to practices of slavery both past and present is the concept of othering, which sees groups of people identified as potential victims of slavery due to their perceived differences from the enslavers. ${ }^{6}$ The focus of the piece then turns to ideas about legality, examining the development of legislation in recognising the state of enslavement and the ensuing governmental responses. Finally, notions of relationships are discussed, including the use of violence, ideas of ownership and property, and profit generated by slavery.

\section{The concept of othering}

Central to, and arguably the first criterion which must be satisfied in enslaving a person, is the idea that they must be different in some way from the enslaver. This construction of difference, or process of othering, is widely

\footnotetext{
${ }^{4}$ Jean Allain, et al "Bellagio-Harvard Guidelines on the Legal Parameters of Slavery," in The Legal Parameters of Slavery: From the Historic to the Contemporary, ed. Jean Allain (Oxford: Oxford University Press, 2012), 375.

5 See for example Paul E. Lovejoy, Transformations in Slavery: A History of Slavery in Africa (Cambridge: Cambridge University Press, 2011), 1; Davis, Inhuman Bondage, 27.

6 'Victim' is the term employed here to refer to those who have been enslaved, both in the past and in the present. Ideally, the individual being referenced would offer their preferred terminology, but this article refers to a generalised notion as opposed to specific individuals. 'Victim' is the most appropriate generalisable term when referring both to those who have escaped enslavement and those who continue to be enslaved. For further discussions on such terminology see; Mustafa Alachkar, "Victims or Survivors?" Avicenna Journal of Medicine 6, no. 3 (2016), 89; Michael Papendick and Gerd Bohner, "Passive Victim - Strong Survivor"? Perceived Meaning and Labels Applied to Women who were Raped (Bielefeld: Bielefeld University, 2017); Jan Van Dijk, "Free the Victim: A Critique of the Western Conception of Victimhood," International Review of Victimology 16 (2009): 1-33.
} 
discussed by both historians and contemporary scholars of enslavement. ${ }^{7}$ Historian Moses Finley asserts that this allocation of 'outsider status' has always been the critical attribute in the condition of enslavement. ${ }^{8}$ Scholars of contemporary slavery also consider this idea of othering, but for some of those critical of the use of the term 'slavery' in the present day, their focus on transatlantic slavery rests predominantly in ideas of race. The idea that race is no longer a key feature of slavery forms an essential part of their argument against contemporary slavery terminology. ${ }^{9}$ While this is a significant point which indicates the lasting legacy of racial inequalities from transatlantic slavery, the terminology of othering includes, but is not exclusive to, ideas of race. It therefore offers a broader application in the contemporary world.

Transatlantic slavery exploited racial difference, in both its justification and its prolonged maintenance across four centuries. The economic success of this system relied on the opportunity and ability of white Europeans to enslave black Africans in a brutal, completely inhuman manner which has been widely documented. From a contemporary perspective the extent of this racism, which 'won wide acceptance and professional authority' across the Western world, is shocking. ${ }^{10}$ During the eighteenth and nineteenth centuries, when transatlantic slavery was at its peak however, the commonly accepted view amongst the Western European public was that of their superiority over uncivilised, 'savage' black Africans. ${ }^{11}$ This understanding was widely spread by popular ideas in religion and through the developing arena of scientific thought, based first on descriptions from the genre of travel literature, but which progressed into biological categorisations. ${ }^{12}$ The methods employed by the white Europeans on the black Africans were so unique in their extremity that critics, including antislavery activist Michael Dottridge, argue that contemporary situations of exploitation

\footnotetext{
7 Othering is a method of depicting a person, or people, as different from the self and thereby can influence the ways that people interact. See Orlando Patterson, Slavery and Social Death: A Comparative Study (Cambridge: Harvard University Press, 1982); Lovejoy, Transformations in Slavery; Davis, Inhuman Bondage.

8 Moses Finley, "Slavery," Encyclopaedia of the Social Sciences, Vol. 14, (New York: Macmillan Co. and Free Press, 1968), 307-313.

9 Julia O'Connell Davidson and Joel Quirk, "Race, Ethnicity and Belonging," June 15, 2015, Beyond Trafficking and Slavery, https://www.opendemocracy.net/beyondslavery/julia-o\%27connell-davidson-joel-quirk/race-ethnicity-andbelonging; Lindsey Beutin, "Black Suffering for/from Anti-trafficking Advocacy," Anti- Trafficking Review 9 (2017): 14-30; Michael Dottridge, "Eight Reasons Why We Shouldn't Use the Term 'Modern Slavery"” October 17, 2017, Beyond Trafficking and Slavery, https://www.opendemocracy.net/beyondslavery/michael-dottridge/eightreasons-why-we-shouldn-t-use-term-modern-slavery

${ }^{10}$ Davis, Inhuman Bondage, 76.

${ }^{11}$ Kathleen Wilson, The Island Race: Englishness, Empire and Gender in the Eighteenth Century (Abingdon: Routledge, 2003), 10-11.

12 Nicholas Hudson, "From "Nation to "Race": The Origin of Racial Classification in Eighteenth-century Thought," Eighteenth Century Studies 29, no.3 (Spring 1996): 249-250.
} 
cannot be defined as slavery because they fail to adequately match the experiences of the victims of transatlantic slavery. ${ }^{13} \mathrm{He}$ is referencing the experiences of the kidnapping and branding of black Africans who were transported in terrible conditions and who suffered much pain and violence in being forced to work long hours for no pay. Dottridge goes further to argue that any use of slavery as a term in the contemporary world 'has the effect of trivialising or relativising historical slavery [referring to transatlantic slavery] and thereby reducing any sense of responsibility for the countries that profited from slavery. This fits neatly into the agenda of white supremacists.' 14 Transatlantic slavery therefore offers a significant case for understanding the implications of othering in the practices of slavery and offers a point of comparison to understand whether the process of othering still has ramifications in the contemporary world. This is discussed further below.

The unique nature of transatlantic slavery, stemming from its distinct racial agenda, has been the subject of much discussion from historians, with David Brion Davis describing it as an 'extreme case' in terms of the extent to which slave masters viewed their slaves as an 'entirely different species'. ${ }^{15}$ There are others, however, who illustrate that the use of race particularly in terms of 'blackness', is part of a longer tradition of justifying enslavement both before and since the period of transatlantic slavery. ${ }^{16}$ Patterson describes the ways in which black skin was, and is still, associated with a status of enslavement in 'almost all Islamic societies.' 17 During the eighteenth and nineteenth centuries in Russia, noblemen reimagined a separate historical origin for Russian serfs and claimed they had black bones, thereby embedding racial difference even when the enslaved were of the same ethnic group. ${ }^{18}$ Paul Freedman also analyses the way in which Western European serfs in the medieval period were frequently reduced to 'subhuman and even black' as a result of their exposure to the sun and soil. ${ }^{19}$ Slavery in ancient India makes reference to race, with enslavement initially linked to dark skin; a concept still present in the Caste system today in cases of debt bondage. ${ }^{20}$ These examples illustrate the complex nature of the association between race and

\footnotetext{
13 Dottridge, "Eight Reasons Why We Shouldn't Use the Term Modern Slavery."

14 Ibid.

15 Davis, Inhuman Bondage, 32.

${ }^{16}$ Patterson, Slavery and Social Death, 58.

17 Ibid. 58.

${ }^{18}$ Peter Kolchin, Unfree Labour: American Slavery and Russian Serfdom (Cambridge: Harvard University Press, 1987), 170-73.

19 Paul Freedman, Images of the Medieval Peasant (Stanford: Stanford University Press, 1999), 300-303.

20 Davis, Inhuman Bondage, 50.
} 
enslavement, throughout history, extending beyond the system of transatlantic slavery.

It is also clear from a wider consideration of enslavement practices throughout history that the use of race as the sole identifying feature of a group to enslave can also be somewhat problematic. As Patterson asserts, 'it is a mistake to generalise the social alienation of the slave as necessarily ethnic.' ${ }^{21} \mathrm{He}$ goes on to state that it was not, as is traditionally accepted, colour differences that became the crucial mark of enslavement in the Americas, but rather a difference in hair type between the Europeans and the Africans. This, he argues, was a consequence of skin colour being 'a rather weak basis of ranked differences in interracial societies'; firstly because of the variations between skin tone being greater than just black and white, secondly as a result of skin exposure blurring distinctions between races, and finally due to miscegenation causing the significance of colour to diminish.22 In addition, Winthrop Jordan describes the way in which the 'we they' distinction that developed between white Europeans and black Africans was 'really a fusion of race, religion and nationality in a generalised conception of us and them.' 23 These arguments illustrate the nuanced nature of the use of race in the system of transatlantic slavery, particularly as it became more embedded in American domestic society. However, as Davis argues, looking at the world today, there can be no doubt that the racial implications of slavery in the Atlantic World have widened the gap between the enslaved and their descendants, and other nonslave groups. ${ }^{24}$ Thus in discussions of transatlantic slavery, it is important to recognise the significance of race alongside additional factors that were embodied in the justification of the enslavement practice, as well as to understand the multifaceted nature of race as a criterion.

The labelling of enslaved people as outsiders is one of the crucial factors that historian Seymour Drescher purports brings together a 'large cluster of analogous institutions and relationships extending across the globe and over millennia as variations on a condition called slavery.' 25 Beyond ideas of race, there have been numerous other characteristics that have been employed to justify enslavement. In the earliest recorded incidents of enslavement in pre-conquest Brazil for example,

\footnotetext{
${ }^{21}$ Patterson, Slavery and Social Death, 7.

22 Patterson, Slavery and Social Death, 61.

${ }^{23}$ Winthrop D. Jordan, White Over Black: American Attitudes Toward the Negro (Baltimore: Penguin Books, 1969), 97.

24 Davis, Inhuman Bondage, 3.

${ }^{25}$ Seymour Drescher, Abolition: A History of Slavery and Antislavery (Cambridge: Cambridge University Press, 2009), 4.
} 
enslavement was the result of captivity following a war. ${ }^{26}$ In societies where enslavement following conquest was common, as in Ancient Rome for example, racial identification was useless as the enslaved blended in with the proletariat. ${ }^{27}$ This resulted in the development of other identification methods, including shaving heads, certain styles of clothing and tattooing or branding. ${ }^{28}$ In a wider view, Davis highlights how the concept of slavery was a way of 'classifying' the most debased social class. ${ }^{29}$ Thus regardless of race, ethnicity, location or time period, a set of distinct stereotypes for enslaved people can be identified. These revolve around ideas of the enslaved being animalistic, or childlike. ${ }^{30}$ These stereotypes reinforce the notion that the enslaved were different, lesser and inhuman, regardless of their origin.

The notion of othering is also clear in situations of contemporary slavery, indicating a significant historical link. Patterson highlights how ethnic and racial distinctions between victim and perpetrator in some cases of contemporary slavery serve as a method of othering the victim, as was apparent in some situations of historic slavery. ${ }^{31}$ Although physical, biological differences are less clearly defined in some examples of contemporary slavery, those who hold people in situations of contemporary slavery tend to see a significant difference between themselves and their victims. As Martig argues, while othering is apparent in situations like Indian debt bondage and Burmese sailors on Thai boats, it need not be solely based on race, but could be constituted by any number of identity factors. ${ }^{32}$ These situations are based on setting some level of categorical difference between perpetrator and victim. Distinguishing the victim as 'other' in this way is a method through which perpetrators may justify the exploitation they enforce on their victims - people they do not consider equal to themselves. As discussed, this was standard practice during many instances of historic slavery.

However, it is not just the racial differentiation between victim and perpetrator that critics raise concern over in relation to discussions of contemporary slavery. A further criticism from this group focuses on a notion of Western superiority possessed by 'activists' and academics. This argument suggests

\footnotetext{
26 Davis, Inhuman Bondage, 27.

27 Patterson, Slavery and Social Death, 61.

${ }^{28}$ Ibid. 61-62.

29 Davis, Inhuman Bondage, 32.

${ }^{30}$ Ibid. 52-53.

${ }^{31}$ Orlando Patterson, "Trafficking, Gender, and Slavery: Past and Present”, in The Legal Understanding of Slavery:

From the Historical to the Contemporary, ed. Jean Allain (Oxford: Oxford University Press, 2012), 322-359.

32 Alexis Jonathan Martig, "Slaving Zones, Contemporary Slavery and Citizenship: Reflections from the Brazilian Case", Studies in Global Slavery 4 (January 2018): 336-359.
} 
that contemporary slavery is an especially Western concept and its use allows white people to believe they are rescuing the vulnerable from 'the darkest corners of the world' thus further embedding the concept of othering. ${ }^{33}$ Historically, this was bound up in the public discourse of abolitionism during the eighteenth and nineteenth centuries and can be seen explicitly in the abolition logo. Manufactured by Wedgwood to huge acclaim, the design featured a kneeling, chained, African enslaved man (later versions were made depicting women) posed with the question: 'Am I not a Man and a Brother'. Contemporary critique of this image, alongside other abolitionist campaigning tools including the Brookes Slave Ship Diagram, depicts these sources as examples of white, British abolitionists removing individuality and agency from the enslaved in their effort to 'gift' them with freedom. ${ }^{34}$ Such imagery overlooks situations in which emancipation was achieved through black agency. Many of these images are now contested in their use by scholars and members of the African community. 35

Practices of othering continue in everyday life, and this expands to issues of ethnicity when it comes to the treatment of victims of contemporary slavery. In the $\mathrm{UK}$, for instance, this can be seen transparently by the figures that represent the number of potential victims of 'modern slavery' who go on to receive Conclusive Grounds decisions. Conclusive Grounds decisions are the second stage of decision making in the process of defining a person as a victim of 'modern slavery' in the UK and they state that on the balance of probability "it is more likely than not" that the individual is a victim of human trafficking or modern slavery. ${ }^{36}$ Those who are from countries that require asylum in the UK are considerably less likely to receive a positive Conclusive Grounds decision than those who have the legal right to live and work in the UK. ${ }^{37}$ In 2017, potential victims who were from a country outside the EU were almost equally likely to receive a negative Conclusive Grounds decision as a positive one (116 and 118 respectively). In comparison, victims from the EU (including the UK) were drastically more likely to receive a positive

\footnotetext{
${ }^{33}$ Garrett Nagaishi, "From Utah to the 'Darkest Corners of the World': The Militarisation of Raid and Rescue", 17 April, 2015, Beyond Trafficking and Slavery, https://www.opendemocracy.net/beyondslavery/garrett-nagaishi/fromutah-to- $\% \mathrm{E} 2 \% 80 \% 98$ darkest-corners-of-world $\% \mathrm{E} 2 \% 80 \% 99$-militarisation-of-raid-and-re.

34 Zoe Trodd, "Am I Still Not a Man and a Brother? Protest Memory in Contemporary Antislavery Visual Culture," Slavery \& Abolition 34, no. 2 (May 2013): 340.

${ }^{35}$ See Trodd, "Am I Still Not a Man and a Brother?”; Celeste-Marie Bernier, Characters of Blood: Black Heroism in the Transatlantic Imagination (Charlottesville: University of Virginia Press, 2012); Marcus Wood, Blind Memory: Visual Representations of Slavery in England and America (London: Psychology Press, 2000), 22-23.

36 “National Referral Mechanism,” National Crime Agency, accessed April 20, 2018, http:// www.nationalcrimeagency.gov.uk/about-us/what-we-do/specialist-capabilities/uk-human-trafficking-centre/nationalreferral-mechanism

37 "National Referral Mechanism Statistics - End of Year Summary 2017," National Crime Agency, accessed March 26, 2018, http://www.nationalcrimeagency.gov.uk/publications/national-referral-mechanism-statistics/2017-nrmstatistics/884-nrm-annual-report-2017/file
} 
Conclusive Grounds decision, with 545 positive and 94 negative decisions. There is clearly a problem here regarding issues of discrimination and of ideas surrounding deserving and undeserving victims, reflecting some of the wider academic discussions regarding notions of the ideal victim. ${ }^{38}$ Rather than highlighting a distinction from historic slavery, this mirrors some of the structural issues at play in the past; a concept discussed further below.

The examples of othering identified in this section reflect the commonalities between the present and the past more accurately than focusing on race during transatlantic slavery alone. By showcasing concepts of othering which embody numerous, more nuanced, characteristics, it is clear that the means through which contemporary perpetrators justify their enslavement of victims, as well as the ways that governments address the issue, are not new.

\section{The legal status of slavery}

While the process of othering in the practices of justifying and tackling enslavement is a similarity reflected in historic and contemporary slavery, one of the crucial differences is the concept of legality. Historic slavery has commonly been a state sanctioned and government sponsored activity, in which wide sectors of society actively participated. In British transatlantic slavery, for example, the legal parameters in place facilitated a common understanding of enslaved people as the property of others and thus the state of enslavement was entirely transparent. 39 After legal abolition in 1833, understandings of slavery became less clear. While slavery has been abolished in all states, an end to the legality of slavery has not equated to an end to slavery itself, nor to an end of the acknowledgement that it continues to exist, as can be exemplified through the continued development of anti-slavery legislation.

Such legislation includes, the international agreement for the suppression of white slave traffic which was developed in 1904 and highlighted discussions of trafficking. This was expanded into a convention in 1910 and ratified by the League of Nations in 1921 where it became the 'International Convention for the Suppression of the Traffic in Women and Children'. The League of Nations then developed the Slavery Convention in 1926, which reverted terminology back from

\footnotetext{
38 For discussions regarding notions of the ideal victim, see: Nils Christie, "The Ideal Victim." In From Crime Policy to Victim Policy: Reorienting the Justice System, ed. Ezzat Fattah (Basingstoke: Palgrave Macmillan, 1986), 17-30; Ronald Weitzer, "The Social Construction of Sex Trafficking: Ideology and Institutionalization of a Moral Crusade." Politics \& Society, 35 (2007), 447-475; Michael Wilson and Erin O'Brien, "Constructing the Ideal Victim in the United States of America's Annual Trafficking in Persons Report." Crime, Law and Social Change 65, no. 1 (2016): $29-45$.

39 Finkleman, "Introduction: The Centrality of Slavery in American Legal Development." In Slavery and The Law, ed. Paul Finkleman (Lanham: Rowman and Littlefield Publishers, Inc., 2002), 5.
} 
traffic to slavery, defining slavery as "the status of a person over whom any or all of the rights attaching to ownership are exercised". ${ }^{40}$ This was expanded with a Supplementary Convention in 1956 to include practices that were considered tantamount to slavery. Despite these discussions of slavery in international law, contemporary slavery continues to be a contested notion and there has been no universally accepted legal classification of slavery since it was a legal practice.

After the legal abolition of the British slave trade in 1807, understandings of the methods of enslavement became less clear as the process of buying and selling people was prohibited. However, those who were already working on plantations in the British colonies remained enslaved. This was further complicated following the abolition of slavery in the British colonies, when the remaining enslaved became 'apprentices' to their masters until 1838.41 Jim Stewart emphasises how the mistreatment of the formerly enslaved continued after emancipation in a way that was essentially 'slavery by another name,' particularly across plantations in the American South. ${ }^{42}$ Although this phrase was coined to reflect systematic racism in post-emancipation America, the idea of 'slavery by another name' can be recognised today through the experiences of victims of contemporary slavery where a 'rescue' can result in worse conditions for the victim than their enslavement. ${ }^{43}$ Although there are criticisms of 'new abolitionists' failing to provide a definition that suitably differentiates between slavery and exploitation, it is clear that the line was also blurred in the past when conditions postemancipation were akin to slavery.

Despite this level of ambiguity, what was made clear by the earlier legal achievement of the abolition of the British slave trade in 1807, was the end of state sponsored slave trading. While forms of enslavement and exploitation continued under British rule in its colonies for a further twenty-six years, the process of trading in human beings was prohibited. This trading ban was quickly extended across a wider geographical area, with British naval ships patrolling the West African coast, the Atlantic Ocean and the Americas, blocking other European

\footnotetext{
40 "Slavery Convention Signed at Geneva on 25 September 1926," UNOHCHR, accessed May 17, 2018, http:// www.ohchr.org/EN/ProfessionalInterest/Pages/SlaveryConvention.aspx

41 "An Act for the Abolition of Slavery throughout the British Colonies; for Promoting the Industry of the Manumitted Slaves; and for Compensating the Persons Hitherto Entitled to the Services of Such Slaves," UK Government (1833), accessed September 14, 2018.

42 James. B Stewart, "The 'New Abolitionists' and the Problem of Race," Beyond Trafficking and Slavery, April 21, 2015, https://www.opendemocracy.net/beyondslavery/james-brewer-stewart/"new-abolitionists'-and-problem-ofrace

${ }^{43}$ Angelo Martins, "Interview with Julia O'Connell Davidson on modern slavery." Theory, Culture and Society, 33 (2016): 381-390.
} 
slave-trading practices. ${ }^{44}$ This state-instigated naval suppression therefore illustrates the shift in British authority views of enslavement from acceptable to unacceptable as a system of trading. In the implementation of the system of suppression there was a new government-sponsored understanding of slave trading as a criminal act, dealt with by retributive action. However, the payment of compensation to slave owners for the loss of their 'property' upon emancipation highlighted substantial legislative hypocrisy by failing to provide consistency in the idea that slavery was wrong. Such a lack of consistency is mirrored in contemporary slavery, where the UK government, for example, reassures the public that 'modern slavery' is one of its priorities, and yet conviction rates in the UK remain negligible. ${ }^{45}$

As this section demonstrates, the concept of legality in relation to slavery has changed significantly from historic to contemporary slavery. However, despite the abolition of slavery in the past it continues to exist in the present with new forms of legislation that seek to manage it.

\section{Relationships in the practice of slavery}

In addition to this discussion about using the legality of slavery to determine the relevance of the term for today's world, there must also be a discussion of how systems of slavery are embedded in a range of societal relations. Kevin Bales asserts that contemporary slavery is a relationship between the perpetrator(s) and the victim(s). ${ }^{46}$ O'Connell Davidson, however, suggests that 'Atlantic World slavery was much more than simply a relationship between individuals. 'Slave' was a status ascribed by the state. It conferred on the enslaved a double status as... 'things' (property)' ${ }^{47}$ This notion of the enslaved as the property of another, is an issue tackled by contemporary slavery scholars through the Bellagio-Harvard Guidelines. The guidelines, as defined in the Introduction were developed by leading property scholars in conjunction with slavery experts. The involvement of these scholars highlights the importance of understandings of property in relation to slavery.

The Guidelines also draw attention to the notion of violence, stating that enslavement will usually 'be supported by and obtained through means such as

\footnotetext{
${ }^{44}$ Richard Huzzey, Freedom Burning: Anti-Slavery and Empire in Victorian Britain. (New York: Cornell University Press, 2012), 65-66.

45 Theresa May, "My Government Will Lead the Way in Defeating Modern Slavery," The Telegraph, July 30, 2016, https://www.telegraph.co.uk/news/2016/07/30/we-will-lead-the-way-in-defeating-modern-slavery

46 Kevin Bales, Testing a theory of modern slavery (Washington: Free the Slaves, 2006).

47 O'Connell Davidson, "The Presence of the Past."
} 
violent force, deception and/or coercion' ${ }^{48}$ Critics of contemporary slavery, however, underline the differences in terms of violence, particularly the violence experienced by the enslaved of transatlantic slavery, as one of the factors which negates the use of slavery as the appropriate term for today. They emphasise how the transportation of black Africans into chattel slavery relied on 'overwhelming physical force at every stage' from kidnap to arrival at their destination. ${ }^{49}$ In contrast, they stress that those who experience physical violence as part of a contemporary slavery situation are uncommon, and that the majority of those labelled victims of contemporary slavery have some degree of agency in the choices that led to their exploitation. Although violence is common in situations of slavery, its presence is not a defining feature and, in contrast to the views of some critics, a victim does not have to report incidents of violence in order to be acknowledged as a victim. ${ }^{50}$

What is key to highlight here is that a lack of physical violence does not mean that a situation cannot constitute slavery, but it emphasises how perpetrators of this crime have changed with the times. Practices of slavery are age-old, however the modalities through which they occur continue to change and reform, as is true of any crime. While historic slavery, including but not exclusive to transatlantic slavery, frequently involved kidnap and violence because of a lack of punishment, changes in transportation and technology provide a wealth of new methods of enslavement for perpetrators today. These include deceiving those who are looking for new opportunities, coercing those who are looking to leave their current situation and bribing those who are desperate. Kidnapping and force are no longer essential components because there is an abundance of other methods that perpetrators can now use to recruit and exploit their victims. In the case of historic slavery, although force and physical violence was one method of enslavement, this was not what exclusively defined a situation as slavery. The end results remain comparable, while the methods of enslavement have changed in response to needs, technologies and legislation.

Another distinction between historic and contemporary slavery exists in the nature of the relationship of the system of slavery to the state (or states) in which it operates. Where historically there were slave societies, today there are societies with slaves. ${ }^{51}$ The former refers to situations in which slavery was part of the norm; it was an accepted aspect of everyday society and the profits generated by

\footnotetext{
48 Allain, et al "Bellagio-Harvard Guidelines on the Legal Parameters of Slavery."

49 O'Connell Davidson, 'The Presence of the Past."

50 O'Connell Davidson, 'The Presence of the Past."; Legislation does not require a person to have suffered physical violence to be recognised as a victim, yet notions of ideal victimhood suggest that a person who has suffered physical violence will be more likely to receive support.

${ }^{51}$ Drescher, Abolition, 6
} 
the enslaved were acknowledged in the radical economic development of countries that benefitted. ${ }^{52}$ In contrast, because slavery is no longer an accepted part of life, given its illegal status, slave states no longer exist, but states continue to be home to victims of slavery in an era in which slavery is considered unacceptable. Both historic and contemporary states in which slavery existed/exists have profited from the exploitation of the enslaved. However, this is to a lesser extent today where slavery does not provide the foundation for economic profit. While slave societies may no longer exist, the relationship between a victim of slavery and the state in which they are enslaved continues to be an important factor in their enslavement. States may no longer confer a slave status upon a person, but the perpetuation of hostile environments and restrictive immigration policies are a pertinent factor in putting individuals at risk of slavery today.

The way in which practices of slavery are considered within relationships, both between individuals as perpetrators and victims, and between the system as a whole and the state(s) within which it operates, are crucial to the understanding of slavery and how the term can be applied to the contemporary world. While these relationships have changed over time, they continue to exist.

\section{Conclusion}

Slavery is a term that has been assigned to practices that span thousands of years across vast geographical locations, which include, but expand far beyond, transatlantic slavery. These situations all have variations, from the perpetrators to the victims and the severity of the conditions to the justifications for enslavement. Despite the differences between examples of slavery, there are features common between them all; features which continue to exist today. Given the variation between the hugely differing experiences of the past which are all defined under the term 'slavery', this article argues that such terminology remains relevant to situations that continue in the present. By discussing three of the features common to all situations of slavery, this article has addressed some of the main criticisms that suggest that 'slavery' is not a suitable term to employ in relation to current situations of extreme exploitation.

Firstly, othering was introduced to highlight how its use has persisted through time. Notions of race are often employed in discussions of how the enslaved were recognised during transatlantic slavery, however, these discussions fail to engage with other historical examples of slavery. While race was undoubtedly a key factor in identifying and justifying enslavement in some situations of historical slavery, it was only one of numerous forms of othering used

52 Ibid. 6. 
to set apart the victims from the perpetrators. Other forms of categorical differences have been used in other examples of historic slavery including differences in hair type and religious beliefs. While racial differences may be less evident in contemporary slavery, the notion of othering is still very much apparent in identifying categories of people to be enslaved and in justifying their suffering.

The article also addresses ideas of legality, where historic slavery was legal but contemporary slavery is not. While this suggests differentiation between historic and contemporary slavery, the change in legal status does not negate a situation from being classed as slavery. Using transatlantic slavery as an example, historically there were clear parameters that identified a person as the property of another. After abolition however, these parameters became much more blurred where situations of extreme exploitation that were akin to slavery, such as apprenticeship, continued to exist, but were no longer classified under the rubric of 'slavery'. While one of the criticisms regarding the use of the terminology of slavery for current situations rests on the fact that there continues to be no universally defined distinction between slavery and exploitation, it is evident that this was also the case in the past when slavery was accepted terminology.

Finally, the features of the relationships associated with practices of slavery were addressed. The Bellagio-Harvard Guidelines stipulate that the powers attaching to the right of ownership should be understood in terms of control instead of property. The reframing of these notions in this way allows for understandings of slavery to extend beyond just those situations in which a person could be legally accepted as the property of another. In this way, the legal status is negated as a defining feature of slavery because it is the control, rather than the ownership, of a person that stipulates their victimhood, thereby allowing further comparison between historic and contemporary slavery. However, relationships in situations of slavery go further than between individuals, and the link between structures and individuals must also be acknowledged. This link was particularly evident in state sanctioned historical examples of slavery, but even after the abolition of slavery, state policies have played a fundamental role in causing individuals to become vulnerable to contemporary slavery. This is particularly apparent through the perpetuation of restrictive and hostile immigration policies.

While the ways in which they have presented themselves may have varied, the commonality of these three features of othering, legality and relationships in practices of slavery have existed regardless of their temporal or geographical location. Using these features as a basis for discussion and comparison, this article has demonstrated how such factors continue to persist today, thereby justifying the use of slavery terminology for situations in the present. 


\section{Bibliography}

Alachkar, Mustafa. "Victims or survivors?" Avicenna Journal of Medicine 6, no. 3 (2016): 89.

Allain, Jean, et al "Bellagio-Harvard Guidelines on the Legal Parameters of Slavery." In The Legal Parameters of Slavery: From the Historic to the Contemporary, edited by Jean Allain, 375. Oxford: Oxford University Press, 2012.

Bales, Kevin. Testing a theory of modern slavery. Washington: Free the Slaves, 2006.

Bernier, Celeste-Marie. Characters of Blood: Black Heroism in the Transatlantic Imagination. Charlottesville: University of Virginia Press, 2012.

Beutin, Lynsey P. "Black Suffering For/From Anti-Trafficking Advocacy." AntiTrafficking Review, September 21, 2017. http://antitraffickingreview.org/ index.php/atrjournal/article/view/261/245.

Christie, Nils. "The Ideal Victim." In From Crime Policy to Victim Policy:

Reorienting the Justice System, edited by Ezzat Fattah, 17-30. Basingstoke: Palgrave Manmillan 1986.

Davis, David Brion. Inhuman Bondage: The Rise and Fall of Slavery in the New World: Oxford: Oxford University Press, 2006.

Dottridge, Michael. "Eight Reasons Why We Shouldn't Use the Term 'Modern Slavery," October 17, 2017, Beyond Trafficking and Slavery, https:// www.opendemocracy.net/beyondslavery/michael-dottridge/eight-reasonswhy-we-shouldn-t-use-term-modern-slavery

Drescher, Seymour. Abolition: A History of Slavery and Antislavery. Cambridge: Cambridge University Press, 2009.

Finkleman, Paul. "Introduction: The Centrality of Slavery in American Legal Development." In Finkleman, Paul (ed.) Slavery and The Law. Lanham: Rowman and Littlefield Publishers, Inc., 2002: 3-26. 
Finley, Moses. "Slavery," Encyclopaedia of the Social Sciences. New York: Macmillan Co. and Free Press, 1968.

Freedman, Paul. Images of the Medieval Peasant. Stanford: Stanford University Press, 1999.

Hudson, Nicholas. "From "Nation to "Race": The Origin of Racial Classification in Eighteenth-Century Thought," Eighteenth Century Studies 29, no.3 (Spring 1996): 247-264.

Huzzey, Richard. Freedom Burning: Anti-Slavery and Empire in Victorian Britain. New York: Cornell University Press, 2012.

Independent Anti-Slavery Commissioner "Priority 5: International Collaboration," accessed July 15, 2018, https:/www.antislaverycommissioner.co.uk/ priorities/priority-5-international-collaboration/

Jordan, W. D. White Over Black: American Attitudes Toward the Negro. Baltimore: Penguin Books, 1969.

Kolchin, Peter. Unfree Labour: American Slavery and Russian Serfdom. Cambridge: Harvard University Press, 1987.

Lovejoy, Paul E. Transformations in Slavery: A History of Slavery in Africa. Cambridge: Cambridge University Press, 2011.

Martig, Alexis J. "Slaving Zones, Contemporary Slavery and Citizenship: Reflections from the Brazilian Case." Studies in Global Slavery 4 (January 2018): 336-359.

Martins, Angelo. "Interview with Julia O'Connell Davidson on modern slavery." In Theory, Culture and Society, 33 (2016): 381-390.

May, Theresa. "My Government Will Lead the Way in Defeating Modern Slavery." The Telegraph, July 30, 2016. https://www.telegraph.co.uk/news/ 2016/07/30/we-will-lead-the-way-in-defeating-modern-slavery

Moussa Iye, Ali. “A Wall of Silence around Slavery," May 6, 2015, Beyond Trafficking and Slavery, https://www.opendemocracy.net/beyondslavery/ undefined/wall-of-silence-around-slavery. 
Nagaishi, Garrett "'From Utah to the 'Darkest Corners of the World': The Militarisation of Raid and Rescue," April 17, 2015, Beyond Slavery and Trafficking. https://www.opendemocracy.net/beyondslavery/garrett-nagaishi/ from-utah-to- $\% \mathrm{E} 2 \% 80 \% 98$ darkest-corners-of-world $\% \mathrm{E} 2 \% 80 \% 99$ militarisation-of-raid-and-re

National Crime Agency. "National Referral Mechanism," accessed April 20, 2018, http://www.nationalcrimeagency.gov.uk/about-us/what-we-do/specialistcapabilities/uk-human-trafficking-centre/national-referral-mechanism.

National Crime Agency. "National Referral Mechanism Statistics - End of Year Summary 2017," accessed March 26, 2018, http:// www.nationalcrimeagency.gov.uk/publications/national-referral-mechanismstatistics/2017-nrm-statistics/884-nrm-annual-report-2017/file.

O'Connell Davidson, J. Modern Slavery: The Margins of Freedom. Hampshire and New York: Palgrave Macmillan, 2015.

O'Connell Davidson, Julia. "Rights Talk, Wrong Comparison: Trafficking and Transatlantic Slavery," June 1, 2015, Beyond Slavery and Trafficking, https://www.opendemocracy.net/beyondslavery/julia-o\%27connelldavidson/rights-talk-wrong-comparison-trafficking-and-transatlantic-sl.

O'Connell Davidson, Julia and Joel Quirk. "Race, Ethnicity and Belonging" June 15, 2015, Beyond Slavery and Trafficking, https:/www.opendemocracy.net/ beyondslavery/julia-0\%27connell-davidson-joel-quirk/race-ethnicity-andbelonging.

O'Connell Davidson, Julia. "The Presence of the Past: Lessons of History for Antitrafficking Work", October 19, 2017, Beyond Trafficking and Slavery, https://www.opendemocracy.net/beyondslavery/julia-o-connell-davidson/ presence-of-past-lessons-of-history-for-anti-trafficking-work.

Papendick, Michael and Gerd Bohner, "Passive victim - strong survivor"? Perceived meaning and labels applied to women who were raped. Bielefeld: Bielefeld University, 2017. 
Patterson, Orlando. "Trafficking, Gender, and Slavery: Past and Present." In The Legal Understanding of Slavery: from the Historical to the Contemporary, edited by Jean Allain, 322-359. Oxford: Oxford University Press, 2012.

Quirk, Joel. The Anti-slavery Project: From the Slave Trade to Human Trafficking. Philadelphia: University of Pennsylvania Press, 2011.

Stewart, James. B "The 'New Abolitionists' and the Problem of Race," April 21, 2015, Beyond Trafficking and Slavery, https://www.opendemocracy.net/ beyondslavery/james-brewer-stewart/'new-abolitionists'-and-problem-ofrace.

Trodd, Zoe. "Am I Still Not a Man and a Brother? Protest Memory in Contemporary Antislavery Visual Culture," Slavery \& Abolition 34, no. 2 (May 2013): 338- 352.

UK Government, "An Act for the Abolition of Slavery throughout the British Colonies; for Promoting the Industry of the Manumitted Slaves; and for Compensating the Persons Hitherto Entitled to the Services of Such Slaves," 1833, accessed September 14, 2018.

UN General Assembly. "Protocol to Prevent, Suppress and Punish Trafficking in Persons, Especially Women and Children, Supplementing the United Nations Convention against Transnational Organized Crime ." Published November 15, 2000. http://www.osce.org/odihr/19223?download=true.

UNOHCHR United Nations Human Rights Office of the High Commissioner. Slavery Convention Signed at Geneva on 25 September 1926.” Accessed May 17, 2018. http://www.ohchr.org/EN/ProfessionalInterest/Pages/ SlaveryConvention.aspx.

Van Dijk, Jan. "Free the Victim: A Critique of the Western Conception of Victimhood." International Review of Victimology, 16 (2009): 1-33.

Weitzer, Ronald. 'The Social Construction of Sex Trafficking: Ideology and Institutionalization of a Moral Crusade.' Politics \& Society, 35 (2007): 447-475.

Wilson, Kathleen. The Island Race: Englishness, Empire and Gender in the Eighteenth Century. Abingdon: Routledge, 2003. 
Approaching Contemporary Slavery Through an Historic Lens: an Interdisciplinary Perspective. Nelson \& Kidd.

Wilson, Michael and Erin O'Brien, "Constructing the Ideal Victim in the United States of America's Annual Trafficking in Persons Report." Crime, Law and Social Change, 65, no. 1 (2016): 29-45.

Wood, Marcus. Blind Memory: Visual Representations of Slavery in England and America. London: Psychology Press, 2000. 